\title{
Learning to Read Big Books: Dante, Spenser, Milton
}

\author{
Christopher A. Hill
}

Department of English and Modern Foreign Languages, University of Tennessee Martin, Martin, TN 38238, USA; chrish@utm.edu

Received: 6 March 2019; Accepted: 18 April 2019; Published: 25 April 2019

check for updates

\begin{abstract}
The interpretive challenges posed by dense and lengthy poems such as Dante's Inferno, Spenser's Faerie Queene, and Milton's Paradise Lost can prove daunting for the average undergraduate reader whose experience of texts has been circumscribed by pedagogical mandates focused on reading for information. While information-retrieval based reading certainly has its place, the experience of reading these longer, more allegorical and symbolic poems can create in the attentive reader a far more valuable kind of learning, understood by Dante and his heirs, all working from Homeric and Virgilian models, as understanding. Each of these long poems pay very close attention to acts of interpretation, foregrounding the experiences of their characters to illustrate the proper way to move from sense, past speculation, to true understanding. Those who heed these lessons, and embrace the experience offered by the poet, find that the daunting task has been outlined as the necessary step to true knowledge rather than mere information.
\end{abstract}

Keywords: Dante; Milton; Spenser

\section{1. "Read It Well"}

In the introductory poem of Ben Jonson's grouping of epigrams in his 1616 Folio, he makes a request of his reader:

Pray thee, take care, that tak'st my book in hand,

To read it well: that is, to understand. (Jonson 1996, p. 35)

Jonson is famously impatient with the wrong kinds of readers-those unable to comprehend his carefully constructed epideictic poems even as he pulls from all the considerable Horatian and Ciceronian resources at his disposal. He certainly held "being understood" as a focal point of his literary and critical practice; one of his greatest professional challenges came in his development of the Jacobean court masque as an allegorical vehicle for moral education. His audience, including King James himself, was predictably more taken by the visual and somatic spectacle of the masque performance than the moral instruction for which it was supposed to be a vehicle. For Jonson the poet, working in whatever secondary medium he requires as a vehicle, passive consumption of a spectacle, no matter how marvelous the invention, is insufficient without the exercise of judgment that leads to understanding. Later autobiographical poems, such as the "Ode to Himself" and his "Epistle to John Selden," express his continuing struggle to bridge the gap between poetic intent and reader response. The understanding Jonson values in his readers-or, ideally, hearers-is necessary so that they can apprehend the ethical qualities marking the very best poetry. However, as he is all too aware, this understanding is not an automatic response; it must be nurtured and trained into being.

Jonson's concern mirrors that of many a teacher facing a great poetic work while trying to educate younger or more inexperienced readers in the arts of understanding. This is particularly urgent in an era when traditional humanities disciplines appear to be a hard sell to students for whom a university degree must demonstrate obvious utility in the broader working world of professional credentialing. 
The task of poetic interpretation is made even more difficult when undergraduate students come to works of the past-especially epic scale poetry-having been trained as consumers or users of informational texts. As the Tennessee state standards for English Language Arts are presented:

The ELA standards are designed to prepare students with the most important knowledge and 21st century literacy skills necessary to succeed in post-secondary and workforce arenas. The standards emphasize critical and divergent thinking, problem solving, active listening, recognition of patterns and anomalies, and evaluation and questioning of source material.

The standards reinforce the three ELA instructional shifts: regular practice with complex text and its academic vocabulary; reading and writing grounded in evidence from literary and informational text; and building knowledge through content-rich literary and informational text. (tn.gov)

The Tennessee English/Language Arts Standards manual for instructors promulgated by the Tennessee State Board of Education makes it very clear: All reading standards (see pp. 25-39) must apply roughly equally to "literary" and "informational" texts, because reading is defined as "a cognitively demanding skill. With careful guidance and instruction, students can fluently read words and sentences, so they can have access to the world of ideas presented to them in print" (Tennessee State Board of Education 2018, p. 26). Though it is beyond the scope or purpose of this essay to criticize the decisions made at administrative levels for primary and secondary English instruction, it is appropriate to point out that these kinds of mandates have significant cognitive effects on the students who labor under them. One effect of reading thus defined is that a student must naturally view any given piece of "serious" written discourse as a series of propositions which only need be remembered and repeated on demand in order to be "understood." Students are thus trained to be consumers of written texts in much the same way that they are perhaps less consciously trained to be consumers of electronic media.

It is unsurprising for a university student to be exposed to at least a portion of a demanding narrative poem such as John Milton's Paradise Lost or Edmund Spenser's The Faerie Queene; these are standard fixtures of literature textbooks and provide touchstones for literature survey classes, as does the Inferno portion of Dante Alighieri's Commedia. My observations of student responses to these poems in a regional public university provides the context for what follows. The affective reach of these poems is undeniable; in the case of Milton, for instance, even the most religiously disinclined and Biblically illiterate student is impressed by the energiea of Milton's blank verse and the grand sweep of his ambition. Many also gladly announce, in writing exercises, that by reading Paradise Lost they have learned a lot about Satan and Hell that they never knew before. Though the experienced reader of Milton might gape at such a statement, the student reaction makes perfect sense and even shows that interpretive effort is not in fact lacking; the gathering of information is the only way they know how to approach the task of reading.

The sore-beset literature professor knows that this is hardly the mode of reading Jonson requests for his own relatively brief and plain-spoken poems, and it is certainly a very long way from Milton's "fit audience, though few" (Milton 1957, 7.31), strenuously sought out in the midst of evil days, "with dangers compassed round/And solitude" (Milton 1957, 7.25-28). The works listed above are not invested merely in narrow doctrinal ends enumerated as in a catechism; they are not merely parables or riddles wherein the answer or lesson is implicit in the phrasing of the beginning. In fact, each epic poem aims at making or "fashioning" (as Spenser highlights in his Letter to Ralegh) not only its narrative characters but also its readers: Those who are provided with a challenging, even daunting experience mirroring the quests and tests about which they are reading. If highly allusive and rhetorically dense poems such as the Commedia or Paradise Lost are valuable to undergraduates, it cannot be merely because they provide "information" about the torments of Hell, or the character of Satan, or the origins of Saint George, and frankly it cannot be because these poems provide the opportunity for instructors to gain measurable assessment data points. Instead, these weighty epics provide an experience that cannot be replicated in other forms of reading. Philip Sidney's Defense of Poetry calls poetry "food for 
the tenderest stomachs" (Sidney 1999, p. 34). In providing tender food, Dante, Spenser, and Milton also carefully usher their readers into scenes of instruction in reading. However dark the wood or steep the path, whatever the burden, the understanding reader will embrace it all as a totality, gaining in the experience forms of knowledge and skill that are much greater than the sum of their parts. These skills and knowledge, once gained, are never static or simple, but can inform every intellectual phase of a student's career. Thus, do epic poems manifest the greatest kind of reading possible, and the greatest teaching of that art they so dramatically require.

\section{Visions of Hell}

The drama inherent in renderings of the underworld, or Hell, provides a bracing example of how reading must be conceived as more than gathering data points. Generally, the poets of these works show how demanding the work can get. The self-consciousness of the narrative structure in the Commedia needs no elaborate unpacking; Dante describes a journey into Hell in Inferno that is instigated and guided by Virgil, both as literary forebear and as physical guide. Dante takes the few tableaux provided by Virgil in the sixth book of The Aeneid and expands on them as set-pieces by which moral and philosophical truths are explored by symbolic representation of specific cases taken from history and myth (See The Spenser Encyclopedia, s.v. Dante Alighieri). As such, Dante's narrator frequently offers direct admonition so that the reader of the poem will remember to look and interpret carefully. For instance, in the tense moments before the gates of Dis, we read the following right before the "herald sent from Heaven" (Alighieri 2003, 9.85) clears the way:

O you whose intellects see clear and whole, gaze on the doctrine that is hidden here

beneath the unfamiliar verses' veil. (Alighieri 2003, 9.61-63)

If the verses serve as a veil for some hidden doctrine, the narrator still urges the reasonable reader to search for what lies beneath them-that is, what the words on the page simultaneously reveal and conceal. This is only one of countless moments when readers are directly enjoined to attend closely to the descriptive imagery. As the monstrous Geryon approaches the narrator at the end of Canto 16, the narrator and author collapse into each other in a remarkably evocative depiction of authorial and interpretive anxiety:

Knowing a truth whose face appears a lie,

a man should always keep his lips shut tight

as long as he can, lest he be tagged with shame

Though he has told the truth; but I cannot

keep silent here, and, Reader, by the notes

of this my Comedy, I swear-and may

They keep in favor long-through that thick air

I saw a figure swimming in the night,

such as would stun the surest heart with wonder. (Alighieri 2003, 16.124-32)

Certainly, one could see in a moment like this an assertion of poetic virtuosity; the description that follows will be so fantastic that the poet is describing something beyond the power of language. Such is the nature of ambitious poetry. From the standpoint of the rhetorical moment involved, such narrative frame-breaking is necessary so that the reader does not merely look, but engages the intellect to see. Geryon is certainly a remarkable and vivid sight all on his own, yet it is also true that such a long self-conscious prologue to the description has our attention firmly fixed by the time he appears. Thus prepared, we can better see the whole, rather than merely the sum, of Geryon's parts. As described in the opening lines of Canto 17, the honest, kindly countenance combined with the serpentine body and furry legs are deliberately jarring. These various parts are literally incongruous, albeit whole rather than mutilated. The arabesques on its sides seem strangely opulent, even hypnotic, perhaps deflecting 
the unwary pilgrim's attention from the "venomous fork" at the end of its tail (Alighieri 2003, 17.1-27). As a monster, Geryon is also named as a sign of deceit, so the reader's struggle is to envision the monstrous while also experiencing bemused and even disgusted wonder. Though Geryon's interstitial appearance is particularly dramatic, the Hell Dante describes is full of sights carrying this same weight; there are, in fact, so many that they easily overwhelm the reader just as they do the narrator. Their number and intensity are relentless and cumulative; the pilgrim's experience becomes the reader's experience-wonder, fear, weariness-in an exemplary symbiosis that Dante deliberately emphasizes.

Edmund Spenser, on the other hand, while also pulling from Virgil, offers comparatively oblique and brief reflections of Hell in the The Faerie Queene-parts of the classical rendering reconfigured for the multifarious geography of "Faery Lond." Redcrosse Knight begins his quest of holiness lost in a dark wood and literally stumbles across a monstrous creature of fraud in a dark cave (Spenser 2001, 1.1), calling to mind both the Homeric and Virgilian source material but also the opening sequence of the Inferno. Poor Fradubio, imprisoned in a tree yet able to speak in 1.2.31-43, is a clever joining of Ovidian metamorphoses (Daphne, Syrinx, and Myrrha, for instance) with the Inferno's wood of the suicides in Canto 13. Both Archimago and Duessa, personifications of malicious deceit in Book 1 , descend into the underworld - the former by using familiar spirits who exit "Morpheus house" with its double gates of ivory and horn (Spenser 2001, 1.1.39-40), and the latter descending into "grisly Pluto's realm" where she witnesses the same torments described by Virgil in The Aeneid and gathered into mythographical handbooks: Ixion's wheel, Sisyphus's stone, Tantalus's thirst, Theseus's chair of forgetfulness, and Hippolytus's dismemberment (Spenser 2001, 1.5.38-45).

Redcrosse Knight himself experiences a kind of damnation when he spends nine months in the hell that is the dungeon of Orgoglio's castle (Spenser 2001, 1.8.38). He is only freed by Prince Arthur's recreation of Christ's harrowing of Hell, wherein he breaks down the dungeon door and physically retrieves the suffering knight who cannot carry himself on his "feeble thighes" (Spenser 2001, 1.8.39-40). The spiritual damage from Redcrosse's descent into the hellish underworld is partially restored by Una's gracious reception of her wayward knight, but must be further painfully cauterized by his purgatorial confrontation with Despair in Canto 9 and his arduous ascent of Mount Contemplation in Canto 10: "Thence forward by that painful way that pas,/Forth to an hill, that was both steepe and hy" (Spenser 2001, 1.10.46).

Spenser's Knight of Temperance enters into another version of Hell in his journey through the Cave of Mammon in Book 2. Whereas Dante's pilgrim has Virgil to protect and exhort him, Guyon must make his journey without a guide. His three-day journey through the realms of night, wherein he sees many of the same classical features of Hades, creates in him a deep lassitude of body and spirit, though he does not ever explicitly fall victim to the various temptations Mammon proffers. He does, however, collapse immediately upon emerging into the daylight. Having had no guide but appetite, and no protection besides the exertion of his own considerable will, his preservation is entirely the work of divine intervention in the person of Prince Arthur, who thus reprises the role he first played in Book One when he rescued Redcrosse Knight from Orgoglio's dungeon. Spenser's versions of Hell or Hades are not the focal points of the characters' quests, though they do illustrate important constitutive aspects of their signal virtues and as such provide scenes where moral truths as character developments can be illustrated narratively.

Milton, meanwhile, dramatically departs both from the classical paradigm and from the stark silence of Dante's Lucifer, stuck in the ice of Cocytus (Inferno Canto 34). While Satan's very first phrase is one borne out of isolation, ruin, and confusion - "If thou beest he" (Milton 1957, 1.84) - he quickly recovers, proving restless and voluble. He commands the attention of the fallen angel and reader alike by the vividness of his character and of his heroic rhetoric, claiming to be the new possessor of Hell and asserting the primacy of his will over the circumstance of his damnation. Vain speculation also claims attention in Hell, for not only are the fallen angels busy creating for themselves castles built from the very stuff mined from Hell's guts, but they also engage in epic scale activities ranging from 
exploration to heroic games to philosophy (Milton 1957, 2.521-628). Those who choose the rigors of exploration discover a topography of horror that recalls the first view of Dante's pilgrim in Inferno:

Thus roving on

In confus'd march forlorn, th' adventrous Bands

With shuddring horror pale, and eyes agast

View'd first thir lamentable lot, and found

No rest: through many a dark and drearie Vaile

They pass'd, and many a Region dolorous,

O'er many a Frozen, many a fierie Alpe,

Rocks, Caves, Lakes, Fens, Bogs, Dens, and shades of death,

A Universe of death, which God by curse

Created evil, for evil only good,

Where all life dies, death lives, and Nature breeds,

Perverse, all monstrous, all prodigious things,

Abominable, inutterable, and worse

Then Fables yet have feign'd, or fear conceiv'd,

Gorgons and Hydra's, and Chimera's dire. (Milton 1957, 2.614-28)

Milton catalogues this hellish topography on an alpine scale so that the attentive reader might be taken aback. Like the cacophony that stuns Dante's pilgrim at the opening of Inferno Canto 3, the assault on the senses is overwhelming. While these scenes are disclosed to the horrified eyes of the lesser fallen angels, the reader's curiosity is not sated; again very much like Dante's pilgrim, we are not allowed to stand and gaze but must move with the narrative into a new phase requiring new responses. Satan's own heroic journey out of Hell, for instance, provides an infernal parody of the heroic voyages undertaken into and out of Hades by Odysseus and Aeneas. We are thereby given multiple frames of reference within which to view the arresting imagery of Hell: The forlorn and shuddering subordinate fallen angels, the fallen archangel adopting the pose of the classical hero, and the dark materials of Milton's literary and historical precursors, including Homer, Virgil, and Dante.

\section{Interpretations of Hell}

In none of these cases do we receive "information" about Hell, though the Dantean and Miltonic depictions are so intense that they seem to be assertions about its true nature, luring the unwary reader into a literalistic misreading along the lines of William Blake's (see The Marriage of Heaven and Hell). The lack of irony in tone, unflagging enargeia in invention, and careful command of vernacular verse forms put the reader under extraordinary tension, even temptation. In order to avoid a "fall," to borrow from Stanley Fish's famous reading of Milton, the reader must work very hard to interpret rather than merely consume (Fish 1997, p. 9). In addition to their careful placement of the reader into scenes where proper interpretation is paramount, each of these writers also provides an admonition: Beware a poor reading.

Spenser, whose epic focus is more diffuse, uses examples of consumption without judgment twice in the Legend of Redcrosse Knight. In Book One, Redcrosse Knight is effortlessly seduced by Duessa in Canto 2 because he "busies his quick eyes" with the affected and fraudulent, though not inconsiderable, beauty of her face rather than opening his "dull ears" to hear what she says (Spenser 2001, 1.2.26). Likewise, when he hears Fraudubio's lamentable tale in the latter part of the same canto he cannot tell what it means except that it seems lamentable; in addition to being distracted by Duessa's strategic swoon (Spenser 2001, 1.2.44-45), he is unable to interpret the tale at this still-early stage of his own education. That he falls victim to Duessa's blandishments in Canto 7, and then almost completely succumbs to Despair in Canto 9, makes his purgatorial education in Canto 10 even more necessary.

Dante's pilgrim cannot be allowed the same luxury of trial and error that Spenser provides to Redcrosse Knight. As such, the pilgrim is put through a rigorous course in interpretation, not allowed to merely consume what he sees. In fact, to the extent that he can see at all, his eyes are too weak to penetrate the gloom: 
So dark it was and deep and bleared with mist, that though I fixed my gaze upon the bottom, I still could not discern a single thing. (Alighieri 2003, 4.10-12)

This description is not as terse as Milton's "darkness visible" (Milton 1957, 1.63), but the effect is the same in both cases: Speculation, in the sense that it involves physical sight of whatever spectacle Hell might present to the senses, must ultimately prove insufficient. Dante's double displacement of the reader from the experience - that is, the reader must receive his or her impressions through the senses of a narrator whose own apprehension is often obscured or doubtful-means that the act of interpretation is especially crucial: As Virgil himself makes clear, sometimes Dante's pilgrim, the reader's only guide, misunderstands or allows his frailty to interpose on his apprehension. To view Hell is to view suffering in extravagant and memorable ways. The weight of such visions is not inconsiderable on an already weakened protagonist: He faints dead away when he sees those abandoned to the whirlwinds at the gates of Hell. He faints for sorrow upon hearing Francesca's story in Canto 5. The suicide in Canto 13 calls forth his pity, and he weeps for pity in Canto 20 at the wrenched bodies of the diviners; he is at this point rebuked by his guide Virgil: "Even now, with all the other fools!" (Alighieri 2003, 20.27). At the beginning of Canto 29, the "mob of souls" makes the pilgrim want to stop and weep. Virgil rebukes him again in Canto 30 when he too curiously eavesdrops on the argument between Sinon and Master Adam-it is "a base desire" (Alighieri 2003, 30.148) to eavesdrop on the wrangling that is tickling his ears. In each of these cases, to be sure, the reader is implicated in the fault criticized in the pilgrim.

Meanwhile, the rigors of the journey tax the pilgrim's moral and physical energies to such an extent that the road is often too hard for him. Sometimes he is carried, as at the end of Canto 19 and in Canto 23. In Canto 24, he simply sits down and threatens to give up; Virgil cajoles him to continue with an appeal to fame and glory: "Turn that to profit, if you understand," he says (Alighieri 2003, 24.57). In other words, though there is a considerable spectacle to be viewed in Hell, the pilgrim is not allowed to be a mere spectator. He must learn to manage his own reactions to what he sees, applying reason to perception so that he might always remember his philosophy (as Virgil enjoins him in 6.106).

Spenser's knights must also confront similar challenges. Redcrosse Knight views a tableau of contrapasso in the House of Pride - that is, the palace ruled by Lucifera-in Canto 4. For instance, Gluttony is depicted as a fat monk on a swine, eating, drinking, and vomiting all at the same time, swollen with fatness and suffering from the dropsy as a result of his overindulgence. Though Redcrosse does not directly take part in the parade of the seven deadly sins, the moral weariness created by his extended exposure to sin, and the combat with Sans Joy, creates a weakness exploited by Duessa when she finds Redcrosse beside the magic fountain in Canto 7, disarmed of his "yron-coted plate" (Spenser 2001, 1.7.2). His susceptibility to her particular brand of temptation is intensified by his physical and moral unreadiness symbolized in this unarmed state and his lassitude: "Crudled cold his corage gan assailed,/And cheerfull blood in faintness chill did melt,/Which like a fever fit through all his body swelt" (Spenser 2001, 1.7.6). Likewise Guyon, as he traverses the Cave of Mammon, views the punishments of Tantalus and Pilate (2.7.56-62) and like Dante's pilgrim is anxious to ask the tormented soul about his fate. However, having been three days in the underworld, he finds that his "vitall powers gan wexe Bothe weake and wan,/For want of food, and sleepe, which to upbeare,/like mightie pillours, this fraile life of man" (Spenser 2001, 2.7.65). It almost costs him his life.

Milton's Hell is not interpreted by passers-through or by outside observers; he puts the work of interpretation into the words of the fallen angels themselves, who, like some of the infernal creatures in Dante's Hell, prefer to think that they are managing their own affairs. Paradise Lost Book Two provides several perspectives on the nature of Hell, and though the narrator has already provided a fairly definitive statement of the power of God's providence (1.209-20), other points of view are debated and even strongly considered (if overdetermined by the manipulations of Satan). Moloch sees the topography of Hell as raw material for weapons of war and the most brutish battle instinct; Belial sees Hell as a painful refuge to be stoically endured as a punishment until the Sovereign grows bored and forgetful; Mammon prefers to colonize it and remake it into a kingdom rising in emulation 
opposite Heaven. Not for nothing is Mammon's suggestion the favorite among the fallen angels until Beelzebub plays his role in suggesting what has been determined will happen anyway.

Even as Satan takes on the trappings of the heroic quest, we do find the other fallen angels engaged in the kind of futile parodies of action described in Dante's Inferno: Heroic games, adventures of exploration, music, and even stoic philosophy. Other parodic features include the infernal parody of the trinity in the incestuous relationships between Satan, Sin, and Death, and the parody of the Tree of Knowledge in Book 10, where the fallen angels are all subjected to a punishment worthy of Dante: Their forms, even the degenerate versions, are transformed to those of serpents, whereupon they crawl to eat of a tree "like that/Which grew in Paradise, the bait of Eve/Used by the tempter" (Milton 1957, 10.550-2). The fruit turns to ashes in their mouths:

They fondly thinking to allay

Their appetite with gust, instead of fruit

Chewed bitter ashes, which the offended taste

With spattering noise rejected: oft they assayed,

Hunger and thirst constraining, drugged as oft,

With hatefulest disrelish writhed their jaws

With soot and cinders filled; so oft they fell

Into the same illusion, not as man

Whom they triumphed once lapsed. (Milton 1957, 10.564-71)

The fruit that turns to ashes is the synecdoche for how Milton's poem addresses false or deficient knowledge, apparently simple in its attainment but disappointing or worse in its substance. This kind of knowledge is, in fact, "illusion," a misunderstanding even of the nature of the true Tree of Knowledge-a point made manifest in Satan's recasting of Adam's "sign of our obedience" to his equivocal question, "do they only stand by ignorance?" (Milton 1957, 4. 428, 515-20). Even after they are confronted with "hatefulest disrelish" - that is, the actual bitter experience of their supposed knowledge-they continue to afflict themselves, though they should have learned better. But this is the reason so much attention is paid to Hell as a dramatic scene with its own actors: The fallen angels-from Satan to every one of his followers-are fallen precisely because they never learned to understand their condition.

\section{4. "To Understand"}

The foregoing descriptions are merely fragments of works written at such massive scale that full comprehension is almost too daunting, especially for the reader looking for mere information. One writes and speaks about fragments and sections of these poems because each single poem encompasses a mythic cosmos. Instead of making the reader traverse a chaos "without bound/Without dimension" (Milton 1957, 2.892-93) like Satan in Paradise Lost Book 2, each single poem provides the above exemplary depictions of interpretation and misinterpretation in order to train the reader-by experience and by example-into the arts of understanding.

One watchword for this learning process comes from a key phrase in Satan's temptation of Eve in Book 9 of Paradise Lost. As the serpent speaks to Eve, he describes how after eating of the fruit of the Tree of Knowledge he finds that his mind has been greatly expanded-so much so that he was able to turn his mind to "speculations high or deep" (Milton 1957, 9.602). Since the episode is made up-Satan never directly touches the Tree of Knowledge, much less the fruit; in fact, his only knowledge of it comes from Adam's discourse about it in Book 4-the speculations he refers to are entirely self-generated and fraudulent. In this way, then, the speculations are merely another birth of Sin from his head (as Sin herself memorably recounts in their reunion before the gates of Hell in Book 2). To speculate is to look, but with faulty vision; it is to peer into the darkness and rely on conjecture as the fallen angels do when they "reason'd high/Of Providence, Foreknowledge, Will, and Fate" (Milton 1957, 2.558-59)—words that play major roles in the discourses to follow. The result of this vain philosophy is to be lost in wandering mazes. They, like their leader, are misled by these 
notions they generate, because though they seem to see details they cannot combine those details to properly inform their reasoning; the shape of the maze is beyond their ken. Neither Dante nor Spenser nor Milton encourages readerly speculation about what their characters experience; that is why each includes so many guiding and shaping segments, whether invocations or corrections or commentaries. This is also why each poet grounds his philosophical and theological discourse in powerful visual idioms that even when not directly allegorical tend to fix abstractions into shape. This is true in Hell, in the House of Alma, in Paradise-in every physical location wherein the actions are placed so as to give them a local habitation and a name. A reader avoiding the fault of speculation understands that every description, every account, is neither given only for itself nor for free association, but for the ways their combinations feed his or her reasoning powers.

The other watchword, as invoked in the opening paragraphs of this essay, is "information." The copiousness of Dante's invention, and his mythic and topical allusiveness, are unsurpassed in weight and variety-though Spenser and Milton are the English poets who most closely approach him in their own particular idioms. Avoiding broad speculation is indeed good; the other temptation is to chase down every particularity like Burton's roving spaniel from The Anatomy of Melancholy. The individual pictures, the descriptions, the miniature dramas are all tempting, and can present themselves as riddles to be solved. Dante chooses to place his moral exempla in historical and mythological figures, sometimes relying on a topicality that seems to be a provocation. Spenser's allegory is particularly powerful this way, tempting the unwary student into footnote seeking-as if there is a key to unlock the meaning of the whole in determining the topical referentiality of Acrasia, Lucifera, or Satyrane. Adam's discourse with Raphael begins to veer into the minutiae of angelic sex and into the particularities of celestial motion - both of which Raphael gently rebukes as beside the point that Adam should attend to. To seek for bare "information" about the movement of the celestial spheres would not actually increase his understanding about the moral task ahead of him. Taking the pointed examples each writer provides, and accepting each man's assertion that the experience of careful interpretation must be fully embraced without shortcut, is the way to read properly.

Each work also balances that topical referentiality and allegorical specificity with a narrative frame- that is, the journey of Dante's pilgrim, the quest of the Spenserian knight, or the epic spiritual struggles of Adam and Eve in the face of their tempter. Each work tests but also allures its reader, gently leading him or her into the interpretive mindset necessary to understand how the pilgrims and protagonists themselves are being educated into the right interpretations of their experiences. The richness in works like these - the value of big, capacious books—is that they are totalizing experiences, resisting any unwise reader's urge to reduce them to lists of facts. The teacher who serves as the student's Virgil, or Palmer, can show how the beauties and challenges of poetry are Sidney's cluster of grapes, providing food for tender stomachs and inviting us further into the vineyard.

Funding: The author received no funding for this project.

Conflicts of Interest: The author declares no conflicts of interest.

\section{References}

Alighieri, Dante. 2003. Inferno. Translated and Edited by Anthony Esolen. New York: Modern Library. Fish, Stanley. 1997. Surprised by Sin, 2nd ed. Cambridge: Harvard UP. Jonson, Ben. 1996. Collected Poems. Edited by George Parfitt. London: Penguin. Milton, John. 1957. Complete Poems and Major Prose. Edited by Merritt Y. Hughes. New York: Macmillan. Sidney, Philip. 1999. A Defense of Poetry. Edited by Jan Van Dorsten. Oxford: Oxford UP. Spenser, Edmund. 2001. The Faerie Qveene. Edited by Albert Charles Hamilton. Harlow: Longman. Tennessee State Board of Education. 2018. Tennessee English/Language Arts Standards. Nashville: Tennessee State Board of Education. 